\title{
STRUCTURE AND FLORISTIC COMPOSITION IN A DENSE OMBROPHILOUS FOREST AREA UNDER FOREST MANAGEMENT
}

\author{
Yasmim de Andrade Ramos ${ }^{1 *}$; Bruno Aurélio Campos Aguiar ${ }^{1}$; Marcos Vinicius Cardoso Silva ${ }^{1}$; Renata Elaine \\ Siqueira Matos²; Maria Cristina Bueno Coelho ${ }^{3}$; Marcos Giongo ${ }^{3}$.
}
${ }^{1}$ Federal University of Tocantins, Postgraduate Program in Forest and Environmental Sciences, Gurupi, Tocantins, Brazil - *yasmimaramos@gmail.com; aguiar.florestal@gmail.com; markuz.cardoso12@gmail.com.
${ }^{2}$ Federal Rural University of Amazonia, Forestry Engineering Course, Belém, Pará, Brazil - renathbr@gmail.com. ${ }^{3}$ Federal University of Tocantins, Center for Environmental Monitoring and Fire Management, Gurupi, Tocantins, Brazil - mariacristina@uft.edu.br; giongo@uft.edu.br
Received on: 03/05/2018 - Accepted on: 17/04/2019

\begin{abstract}
Resumo
Estrutura e composição florística em área de Floresta Ombrófila Densa sob manejo florestal. O objetivo do presente trabalho é apresentar a fitossociologia e florística de um fragmento de Floresta Ombrófila Densa sob manejo florestal no município de Portel, Pará. Foram amostrados 6 conglomerados, divididos em parcelas secundárias e terciarias totalizando 120 unidades amostrais de 0,4 hectares cada, nas quais foram medidos todos os indivíduos arbóreos com diâmetro a altura do peito (DAP), a 1,30 m do nível do solo, acima de $10 \mathrm{~cm}$ além de realizar a identificação botânica e realizar os cálculos dos paramêtros de equabilidade e similaridade florística. Foram registrados 3.586 indivíduos, distribuídos em 42 famílias, 121 gêneros e 174 espécies. As famílias Fabaceae, Lecythidaceae e Sapotaceae foram as que obtiveram os maiores IVIF e a maior representatividade de indivíduos. As espécies Eschweilera coriacea (DC.) S.A.Mori., Vouacapoua americana Aubl. e Tetragastris altissima (Aubl.) Swart foram as que tiveram os maiores IVI e dentre os dez maiores resultados destacamos Syzygiopsis oppositifolia Ducke, Manilkara dardanoi Ducke com grande potencial madeireiro. A média do índice de diversidade de Shannon entre as parcelas foi de 3,82 e o da Equabilidade de Pielou 0,84 mostrando que a área apresenta alta diversidade florística além de possuir grande potencial para as atividades do manejo florestal.

Palavras - chave: unidades amostrais; diversidade; Amazônia Legal.
\end{abstract}

\begin{abstract}
This study shows the phytosociology and floristics of a Dense Ombrophilous Forest fragment under forest management in Portel city, Pará State. Six conglomerates were sampled, divided into secondary and tertiary plots totaling 120 sample units of 0.4 hectares each, in which all trees with diameter at breast height $(130 \mathrm{~cm}$ above ground; DBH) above $10 \mathrm{~cm}$ were measured. These individuals were botanically identified, and evenness and floristic similarity were calculated. There were 3,586 individuals distributed in 42 families, 121 genera, and 174 species. Families Fabaceae, Lecythidaceae, and Sapotaceae were the ones that obtained the highest IVI and the highest representativity of individuals. Species Eschweilera coriacea (DC.) S.A.Mori, Vouacapoua americana Aubl., and Tetragastris altissima (Aubl.) Swart were the ones with the highest IVI. Among the ten highest results, we highlight Syzygiopsis oppositifolia Ducke and Manilkara dardanoi Ducke, with great potential for timber production. The Shannon diversity index averaged 3.83 between the plots, and the Pielou evenness averaged 0.84 , showing that the area presents high floristic diversity and great potential for forest management activities.

Keywords: sample units; diversity; Legal Amazon.
\end{abstract}

\section{INTRODUCTION}

Brazil is considered one of the most important countries when it comes to world biodiversity. The country comprises about one third of the world's tropical forests, which occupy an area of about 4.2 million km (DA SILVA et al., 2008). These different forest environments are formed by a rich and varied flora, which is most of the time unique to each environment. Lowland Dense Ombrophilous Forest is the most representative forest formation within the Amazon biome, comprising about $65 \%$ of the total area. Its main characteristics include ombrothermal climate, i.e., climate with high temperatures and high rainfall; closed canopy formation, with trees from 25 to 30 $\mathrm{m}$ in height; DBH mostly above $40 \mathrm{~cm}$; and high species diversity (OLIVEIRA et al., 2008). Moreover, dystrophic latosols predominate in these environments and it is possible to observe the presence of families of pantropical dispersion, present throughout the continent, such as Fabaceae, Sapotaceae, and Lecythidaceae. The latter is considered typical, that is, with remarkable physiognomies in the places where it is presented (IBGE, 2012).

Due to environmental degradation and lack of information about these forest formations, research is needed to seek knowledge about the local flora and its possible preservation (SILVA et al., 2014). Floristic and

FLORESTA, Curitiba, PR, v. 49, n. 4, p. 793 - 802, out/dez 2019.

Ramos, Y. A. et.al.

ISSN eletrônico 1982-4688

DOI: $10.5380 /$ rf.v49 i4.59264 
phytosociological surveys are an important tool for studies of successional stages, since succession of forest species occurs in a continuity of floristic and structural changes that occur in the ecosystem. Moreover, research enables verifying the influences of anthropic actions on the type of forest formation studied (CONDÉ \& TONINI, 2013).

Floristic, phytosociological, and diameter distribution studies are necessary to understand the development of a forest, especially where there is great diversity. These studies contribute to the preservation, conservation and, if necessary, recovery of these areas (DOS SANTOS et al., 2017).

Through several studies conducted in the Amazon, such as those carried out by Almeida et al. (2012), Castro (2018), and Condé and Tonini (2013), it can be seen that lowland forest environments present a high diversity, with a large occurrence of rare species (few individuals of the same species) and with highly variable similarity values. Information obtained from these analyses are essential tools for recognizing the potential of the area and strategies for proper forest management (CASTRO et al., 2018).

Proper forest management practices guarantee the preservation of natural resources, and thus the forest can develop over a long period of time without impairment to its cycle (ESPADA et al., 2015). Brazilian Federal Law No. 11284/2006 complements that economic, environmental, and social benefits are obtained with forest management, without altering the mechanisms that sustain the ecosystem.

In this context, this study analyzes and discusses the structure and floristic composition of a Dense Ombrophilous Forest fragment under forest management in Portel city, Pará State.

\section{MATERIALS AND METHODS}

\section{Study area characterization}

The study area comprises a Dense Ombrophilous Forest fragment in Uberlândia Farm, located in the Alto Pacajá region, and covers 4 municipalities: Portel, Bagre, Baião, and Oeiras do Pará. The total area of the farm is 153,155.02 hectares. It belongs to the Martins Agropecuária S/A Group and is leased to the company LN Guerra Indústria e Comércio de Madeiras LTDA, which uses forest resources through reduced impact forest management practices since mid-2014.
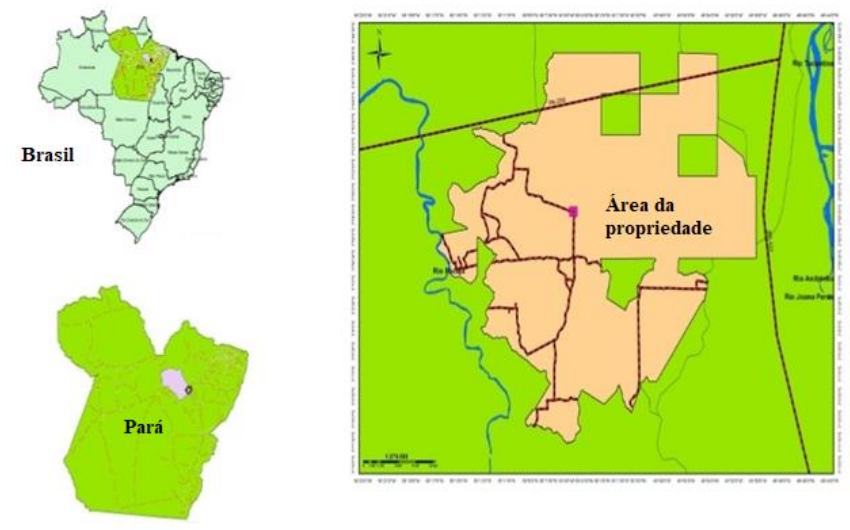

Figure 1. Location of Uberlândia Farm in Pará State, Brazil.

Figura 1. Localização da Fazenda Uberlândia no Estado do Pará, Brasil.

The property is located in a region whose climate is classified by Köppen as "Am", humid tropical (ALVARES et al., 2013), characterized by monsoon rainfall and a short dry season, but with sufficient humidity to supply the rainforest. It receives $2,400 \mathrm{~mm}$ of rain annually, the average air temperature is $26^{\circ} \mathrm{C}$, and the relative humidity above $85 \%$.

Dystrophic Yellow Latosol, with clayey texture, and concretionary dystrophic Yellow Latosol, also with clayey texture, are the predominant soils of the region. The property is located in the low Amazon plateau or Lower Amazon, a region of low plateaus with emergent vegetation (DOS SANTOS et al., 2013).

Five types of forest formations were found in the property area, which were described and classified according to IBGE (2012). The region where the study was conducted corresponds to a Dense Ombrophilous Forest, which occupies an area of about 42,242.04 ha. This vegetation type is characterized by dense, closed, and 
compact canopy, with trees ranging from 25 to $30 \mathrm{~m}$ in height, where it is common to find species Bertholletia excelsa H. B. K., Dinizia excelsa Ducke, Hymenaea coubaril L., Manilkara huberi (Ducke) Chevalier, and Handroanthus serratifolia (Vahl) G. Nicholson in the emerging strata (ALMEIDA et al., 2012).

\section{Sampling theory}

As recommended by Queiroz et al. (2011), the sampled units followed the Maltese-cross-shaped schematic drawing (as shown in Figure 2), where each conglomerate (plot) had a rectangular shape of $5 \mathrm{~km}$ x 5 $\mathrm{km}$. Each plot consisted of 5 secondary units also arranged crosswise from their center, sized $500 \mathrm{~m}$ x $500 \mathrm{~m}$, and $200 \mathrm{~m}$ equidistant from each other, totaling 8 ha. These secondary units were composed of 4 tertiary units sized $20 \mathrm{~m} \times 200 \mathrm{~m}$ or 0.4 ha each, $50 \mathrm{~m}$ far from the central point, totaling 120 sample units.

Secondary and tertiary units were located using a compass, which measured the angles that delimited these units in the area. The reference for this delimitation was the central point of the primary units.

The area was sampled as a function of a certain percentage of the population area to be sampled, as described by Soares $e t$ al. (2006). Thus, an initial $\mathrm{N}$ of 48 hectares ( 120 sample units $\mathrm{x} 0.4$ hectares $=48$ hectares) was obtained for the area in question, which corresponds to about $0.11 \%$ of the total area.

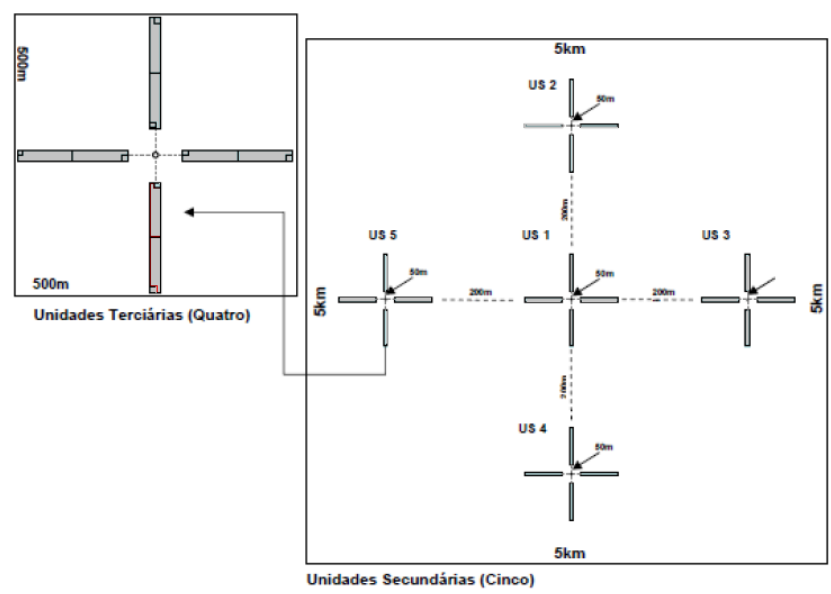

Figure 2. Schematic drawing of the conglomerates (sample plots) distributed in the study area.

Figura 2. Desenho esquemático dos conglomerados (parcelas amostrais) distribuídas na área de estudo.

An inventory was made for the primary units, in which all tree individuals with DBH (diameter at breast height) above $10 \mathrm{~cm}$ were measured. In addition to $\mathrm{DBH}, \mathrm{CH}$ (commercial height) was visually estimated for each individual assessed.

During collection, species were identified only by their popular name with the help of a company employee. Subsequently, the scientific name of the collected botanical materials was confirmed by comparing them with exsiccates in the Herbarium of the Paraense Museum Emilio Goeldi (MPEG), Pará State. The names of the species and their respective authors and synonyms were updated from the List of Brazilian Flora Species (MARTINS \& MRTINELLI,, 2013).

\section{Forest structural analysis}

For forest structural analysis, all phytosociological parameters were calculated:

Absolute and relative frequencies:

$$
A F=\frac{u i}{u t} \times 100 \quad R F=\frac{A F}{\sum A F} \times 100
$$

Where $\mathrm{AF}=$ absolute frequency of the ith species in the plant community; $\mathrm{RF}=$ relative frequency of the ith species in the plant community; ui = number of sampling units in which the ith species occurs; ut $=$ total number of sampling units.

Density, also known as abundance, which corresponds to the number of individuals of each species in the forest area formation; estimated in absolute and relative values, according to the expressions below:

$$
A D=\frac{n}{A} \quad R D=\frac{A D}{T D} \times 100
$$

Where $\mathrm{AD}=$ absolute density of the ith species, expressed in number of individuals per hectare; $\mathrm{n}=$ number of individuals of the ith species in the sample; $\mathrm{A}=$ total sampled area, expressed in hectare; $\mathrm{RD}=$ relative density (\%) of the ith species.

FLORESTA, Curitiba, PR, v. 49, n. 4, p. 793 - 802, out/dez 2019.

Ramos, Y. A. et.al.

ISSN eletrônico 1982-4688

DOI: $10.5380 /$ rf.v49 i4.59264 
Dominance, which is the estimate of the basal area of both the species and the forest area, expressed in hectare; obtained by the following expressions:

$$
D o A=\frac{B A}{A} \quad D o R=\frac{D o A}{D o T} \times 100
$$

Where DoA $=$ absolute dominance of the ith species, in $\mathrm{m}^{2} / \mathrm{ha} ; \mathrm{BA}=$ basal area of the ith species in the sampled area, in $\mathrm{m}^{2} ; \mathrm{A}=$ sampled area, in hectare; DoR = relative dominance $(\%)$ of the ith species.

The importance value index (IVI) was calculated from the sum of the three relative parameters: frequency, density, and dominance.

\section{Plot characterization}

$$
I V I=(\mathrm{RD}+\mathrm{RFi}+\mathrm{DoR})
$$

The Shannon-Weaver index (H') and Pielou evenness index (J') were used to estimate species diversity in each sampling plot:

$$
H^{\prime}=\sum_{i=1}^{S}[p i \ln (p i)], \text { with } p i=n i / N \quad J=\frac{H^{\prime}}{\ln (S)}
$$

The Sorensen index was calculated to determine the floristic similarity between the sampling plots, being given by the following expression:

$$
\text { SOij }=\frac{2 c}{a+b}
$$

Where SOij is the Sorensen index; $\mathrm{c}$ is the number of species common to both plots; $\mathrm{a}$ is the number of species occurring in plot 1 ; and $\mathrm{b}$ is the number of species occurring in plot 2.

The values obtained were interpreted by the unweighted pair group method using arithmetic averages (UPGMA), represented in a dendrogram that was obtained through the MVSP software, using the value of 0.80 for separation of the groups.

\section{RESULTS}

\section{Floristic composition}

The 30 species with the highest Importance Value Index (IVI) totaled about $71 \%$ of all individuals sampled, as shown in Table 1, which also shows the level of extinction threat for each of these. In the 6 sampling units randomly distributed in the area, 3,586 individuals were found, distributed in 42 families, 121 genera, and 174 species. Of this total, 21 species were not identified.

Table1. Distribution in descending order of the 30 most important species in Importance Value Index (IVI) in the studied forest area, with the respective number of individuals per species $(\mathrm{N})$, absolute frequency (AF), relative frequency (RF), absolute density (AD), relative density (RD), absolute dominance (DoA), relative dominance (DoR), and threat level (TL). NE: not evaluated; EN: endangered; VU: vulnerable; LC: less concerning.

Tabela 1. Distribuição em ordem decrescente das 30 espécies que mais se destacaram em Índice de Valor de Importância (IVI) na área de floresta estudada, sendo número indivíduos por espécie (N), frequência absoluta (FA), frequência relativa (FR), densidade absoluta (DA), densidade relativa (DR), dominância absoluta (DoA), dominância relativa (DoR) e o nível de ameaça (NA): NE: não avaliada; EN: em perigo; VU: vulnerável; NT: quase ameaçada; LC: menos preocupante.

\begin{tabular}{llllllllll}
\hline Species & N & AF & RF & AD & RD & DoA & DoR & IVI\% & TL \\
\hline Eschweilera coriacea (DC.) S.A.Mori & 473 & 0.89 & 4.96 & 9.85 & 13.2 & 2.92 & 8.06 & 26.29 & NE \\
\hline Vouacapoua americana Aubl. & 270 & 0.85 & 4.72 & 5.63 & 7.58 & 2.52 & 6.94 & 19.24 & EN \\
\hline Tetragastris altissima (Aubl.) Swart & 114 & 0.39 & 2.18 & 2.38 & 3.20 & 1.36 & 3.74 & 9.12 & NE \\
\hline Syzygiopsis oppositifolia Ducke & 88 & 0.47 & 2.59 & 1.83 & 2.47 & 1.40 & 3.86 & 8.92 & NE \\
\hline Inga heterophylla Willd. & 114 & 0.50 & 2.78 & 2.38 & 3.20 & 0.72 & 1.99 & 7.97 & NE \\
\hline Macrolobium limbatum Spruce ex Benth. & 66 & 0.38 & 2.08 & 1.38 & 1.85 & 1.16 & 3.19 & 7.12 & NE \\
\hline Eschweilera odora (Poepp.) Miers & 97 & 0.39 & 2.18 & 2.02 & 2.72 & 0.75 & 2.07 & 6.97 & NE \\
\hline Manilkara dardanoi Ducke & 69 & 0.40 & 2.22 & 1.44 & 1.94 & 0.95 & 2.62 & 6.78 & VU \\
\hline Couratari oblongifolia Ducke et R. Knuth & 62 & 0.33 & 1.85 & 1.29 & 1.74 & 1.04 & 2.86 & 6.45 & $\mathrm{NE}$ \\
\hline Sagotia brachysepala (Müll.Arg.) Secco & 82 & 0.42 & 2.32 & 1.71 & 2.30 & 0.62 & 1.72 & 6.34 & $\mathrm{NE}$ \\
\hline $\begin{array}{l}\text { Macrosamanea pubiramea (Steud.) Barneby } \\
\text { \& J.W. Grimes }\end{array}$ & 72 & 0.36 & 1.99 & 1.50 & 2.02 & 0.71 & 1.96 & 5.97 & $\mathrm{NE}$ \\
\hline Micropholis egensis (A.D.C) Pierre & 68 & 0.38 & 2.08 & 1.42 & 1.91 & 0.68 & 1.88 & 5.87 & $\mathrm{NE}$ \\
\hline
\end{tabular}




\begin{tabular}{llllllllll}
\hline Carapa guianensis Aubl. & 69 & 0.38 & 2.08 & 1.44 & 1.94 & 0.61 & 1.67 & 5.69 & $\mathrm{NE}$ \\
\hline Piptadenia suaveolens Miq. & 51 & 0.32 & 1.76 & 1.06 & 1.43 & 0.91 & 2.50 & 5.69 & $\mathrm{NE}$ \\
\hline Dinizia excelsa Ducke & 32 & 0.22 & 1.20 & 0.67 & 0.90 & 1.29 & 3.57 & 5.67 & $\mathrm{NE}$ \\
\hline Rollinia exsucca (Dun.) A. DC. & 71 & 0.34 & 1.90 & 1.48 & 1.99 & 0.43 & 1.17 & 5.06 & $\mathrm{NE}$ \\
\hline $\begin{array}{l}\text { Chrysophyllum lucentifolium subsp. } \\
\text { pachycarpum Pires \& T.D.Penn. }\end{array}$ & 82 & 0.29 & 1.62 & 1.71 & 2.30 & 0.40 & 1.11 & 5.03 & $\mathrm{NE}$ \\
\hline Cecropia ficifolia Warb. ex Snethl. & & & & & & & & & \\
\hline Pouteria laurifolia Radlk. & 71 & 0.34 & 1.90 & 1.48 & 1.99 & 0.41 & 1.12 & 5.01 & $\mathrm{NE}$ \\
\hline Chomelia paniculata (Bartl. ex DC.) Steyerm. & 41 & 0.22 & 1.20 & 1.73 & 2.33 & 0.29 & 0.80 & 4.33 & $\mathrm{NE}$ \\
\hline Eschweilera amara (Aubl.) Ndz. & 52 & 0.25 & 1.39 & 1.04 & 1.40 & 0.40 & 1.11 & 3.90 & $\mathrm{NE}$ \\
\hline Pouteria bilocularis (H.K.A.Winkl.) Baehni & 38 & 0.22 & 1.20 & 0.79 & 1.07 & 0.57 & 1.57 & 3.84 & $\mathrm{NE}$ \\
\hline Lecythis alutacea (A.C.Sm.) S.A.Mori & 28 & 0.19 & 1.07 & 0.58 & 0.79 & 0.61 & 1.69 & 3.54 & $\mathrm{NE}$ \\
\hline Moronobea candida Ducke & 55 & 0.20 & 1.11 & 1.15 & 1.54 & 0.26 & 0.72 & 3.38 & $\mathrm{NE}$ \\
\hline Protium amazonicum (Cuatrec.) Daly & 38 & 0.19 & 1.07 & 0.79 & 1.07 & 0.43 & 1.18 & 3.31 & $\mathrm{NE}$ \\
\hline Pouteria anomala (Pires) T.D.Penn. & 39 & 0.21 & 1.16 & 0.81 & 1.09 & 0.27 & 0.74 & 2.99 & $\mathrm{NE}$ \\
\hline Goupia glabra Aubl. & 25 & 0.15 & 0.83 & 0.52 & 0.70 & 0.51 & 1.40 & 2.94 & $\mathrm{NE}$ \\
\hline Pouteria oblanceolata Pires & 37 & 0.22 & 1.20 & 0.77 & 1.04 & 0.25 & 0.69 & 2.93 & $\mathrm{NE}$ \\
\hline Hymenaea courbaril L. & 22 & 0.18 & 0.97 & 0.46 & 0.62 & 0.43 & 1.18 & 2.77 & $\mathrm{LC}$ \\
\hline Ocotea neesiana (Miq.) Kosterm. & 27 & 0.18 & 1.02 & 0.56 & 0.76 & 0.23 & 0.63 & 2.41 & $\mathrm{NE}$ \\
\hline
\end{tabular}

The botanical families with the largest number of individuals were Fabaceae (882), Lecythidaceae (769), and Sapotaceae (609). Together, these three families correspond to $63 \%$ of the total individuals sampled.

Table 1 shows that among the thirty species with the highest IVI, Eschweilera coriacea (Mata-matá), Vouacapoua americana (Acapu), Tetragastris altissima (Barrote), Syzygiopsis oppositifolia (Guajará bolacha), and Inga heterophylla (Ingá) were highlighted, with the highest representativeness in the sample units. In this study area, these five species were highlighted also due to their high values of relative density and dominance, that is, they have a much larger percentage of total individuals in the area.

Some species within the area were also shown to present a degree of threat, with Vouacapoua americana being in danger of extinction; Manilkara dardonai vulnerable to extinction; Syzygiopsis oppositifolia and Pouteria opposita almost endangered; and Hymenaea courbaril in a more comfortable situation regarding this threat.

\section{Ecological classification and species structure}

Figure 3 shows the phytosociological parameters of the ten species with the highest IVI. Together, these species correspond to about $40 \%$ of the total sampled individuals. The studied forest area was characterized by a large number of individuals concentrated in a few botanical families. Figure 4 graphically shows the ten families with the largest family importance value index (FIVI), highlighting Fabaceae (65.63\%), Lecythidaceae (48.19\%), and Sapotaceae $(42.53 \%)$, which together make up about $52 \%$ of the total FIVI.

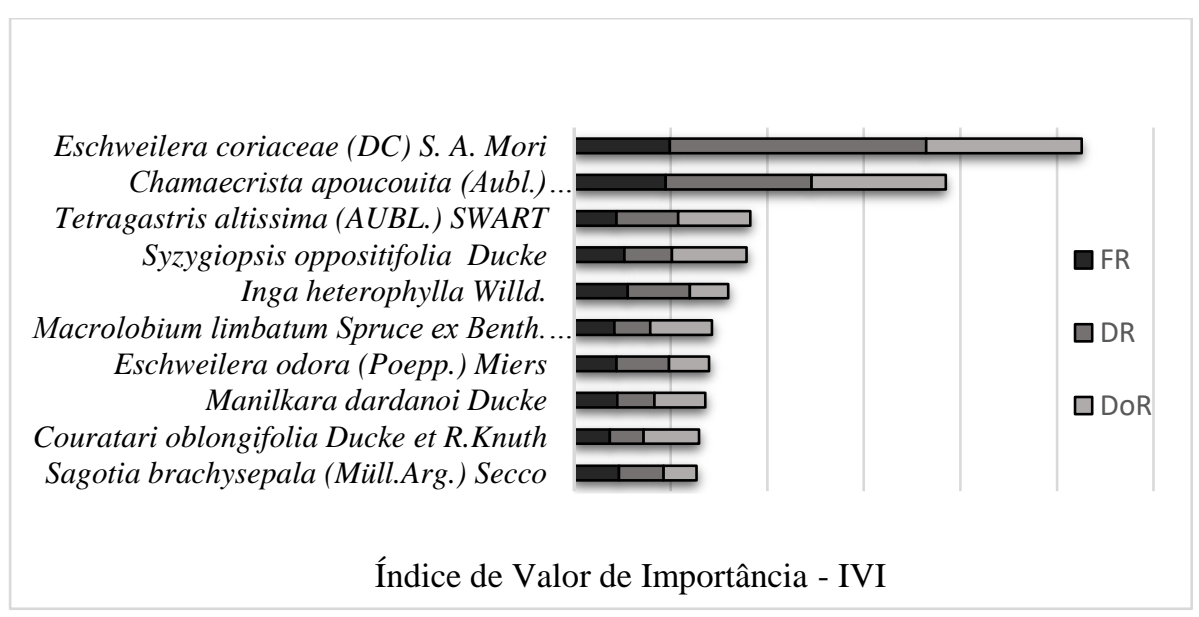

Figure 3. Phytosociological parameters of the 10 species sampled with the highest importance value index. RD, DoR, and RF correspond, respectively, to relative density, dominance, and frequency.

Figura 3. Parâmetros fitossociológicos das 10 espécies amostradas com maior índice de valor de importância. DR, DoR, e FR correspondem, respectivamente, à densidade, dominância e frequência relativas.

FLORESTA, Curitiba, PR, v. 49, n. 4, p. 793 - 802, out/dez 2019.

Ramos, Y. A. et.al.

ISSN eletrônico 1982-4688

DOI: $10.5380 /$ rf.v49 i4.59264 
About eighteen percent of the species observed in the studied area had only one individual, among them we can mention: Cedrela odorata L., Cordia sagotii I.M.Johnst, Licania rigida Benth, Brosimum alicastrum Swartz, and Pachira macrocalyx Ducke.

Among the ten species with the highest IVI, we highlight Syzygiopsis oppositifolia - almost endangered, Manilkara dardanoi - vulnerable, and Couratari oblongifolia. Besides their ecological importance, these species have a commercial importance. Notwithstanding, the area is used for forest management purposes and, according to the legislation, these species should not be cut but rather preserved because they are endangered (BRASIL, 2014).

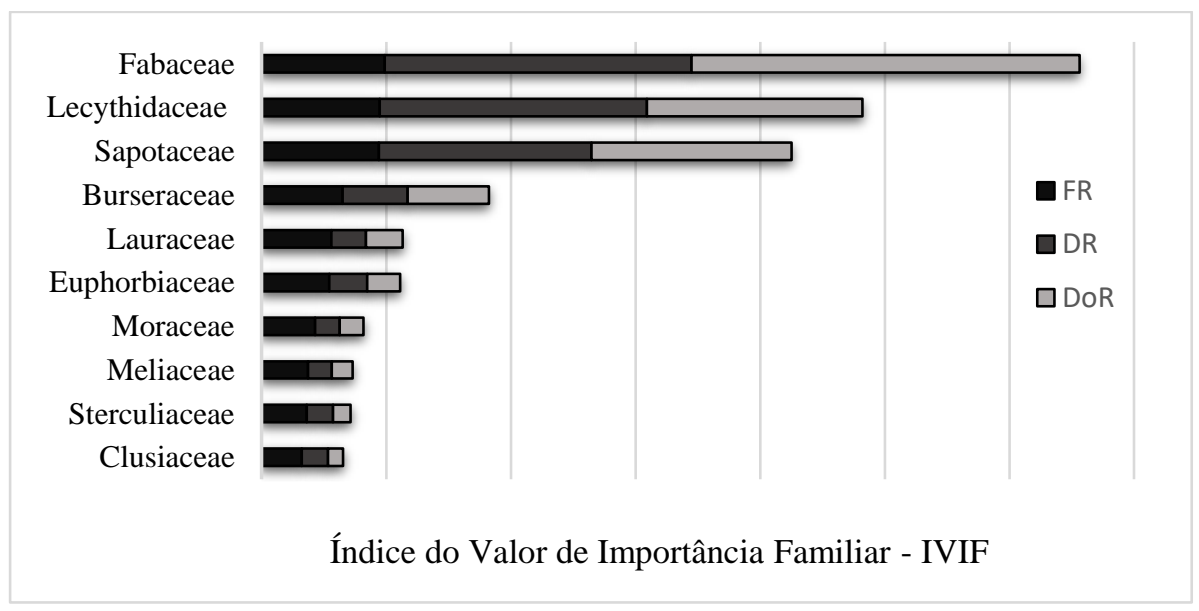

Figure 4. Phytosociological parameters of the 10 families sampled with the highest value of family importance. $\mathrm{RD}, \mathrm{DoR}$, and RF correspond, respectively, to relative density, dominance, and frequency.

Figura 4. Parâmetros fitossociológicos das 10 famílias amostradas com maior valor de importância familiar. DR, DoR, e FR correspondem, respectivamente, à densidade, dominância e frequência relativas.

\section{Characterization of the sampling plots}

The average H' index was 3.83, highlighting plot 6 , which presented the highest value (3.95). The average $\mathrm{J}$ ' index was 0.84 , and plot 5 showed the best result, as can be seen from the data in Table 2 .

Table 2. Total number of trees, families, and species of each sampling plot of the forest inventory, with their respective value of Shannon-Weaver index (H') and Pielou Evenness (J') index.

Tabela 2. Número total de árvores, famílias e espécies de cada parcela amostral do inventário florestal, com o respectivo valor do índice de Shannon-Weaver (H') e Equabilidade de Pielou (J).

\begin{tabular}{cccccc}
\hline PLOT & INDIVIDUALS & FAMILIES & SPECIES & H' & J' \\
\hline $\mathbf{1}$ & 794 & 30 & 85 & 3.61 & 0.81 \\
\hline $\mathbf{2}$ & 709 & 35 & 103 & 3.88 & 0.84 \\
\hline $\mathbf{3}$ & 585 & 34 & 90 & 3.77 & 0.83 \\
\hline $\mathbf{4}$ & 514 & 31 & 86 & 3.82 & 0.85 \\
\hline $\mathbf{5}$ & 439 & 31 & 87 & 3.9 & 0.86 \\
\hline $\mathbf{6}$ & 545 & 31 & 102 & 3.95 & 0.85 \\
\hline Average & 597.67 & 32.0 & 92.17 & 3.83 & 0.84 \\
\hline
\end{tabular}

Table 2 shows that the Shannon index, calculated for each plot, ranged from 3.61 to 3.95. The average diversity index between plots was 3.83 .

The Pielou Evenness Index (J') showed a value above 0.80 in all plots, reaffirming the high floristic diversity in the studied area.

The diameter distribution behaved as expected for unequal forests, with a distribution curve resembling an inverted $\mathbf{J}$ (Figure 5). One can also observe that there is a large concentration of trees in the first diameter classes (almost $79 \%$ of individuals per hectare up to a limit of $30 \mathrm{~cm}$ ), with a reduction of this concentration in larger diameter classes. 




Figure 5. Diameter distribution of all individuals sampled in the study area.

Figura 5. Distribuição diamétrica de todos os indivíduos amostrados na área de estudo.

These population structure patterns, with many individuals in smaller classes and relatively few ones in large diameter classes, have also been found in many of the most common tree species in lowland forests (CARIM et al., 2013).

The horizontal structure shows that $43.24 \%$ of the individuals are between $10-30 \mathrm{~cm} ; 39.85 \%$ between $30-50 \mathrm{~cm}$; and $16.91 \%$ are larger than $50 \mathrm{~cm}$. The vertical structure, in turn, shows that $23.25 \%$ of the individuals are between 6-9 $\mathrm{m}$ in height; $55.39 \%$ between $11-13 \mathrm{~m} ; 17.12 \%$ between $14-16 \mathrm{~m}$; and $3.80 \%$ are higher than 17 $\mathrm{m}$. The average DBH was $36.09 \mathrm{~cm} \pm 14.47 \mathrm{~cm}$, and the average total height was $11.35 \mathrm{~m} \pm 2.78 \mathrm{~cm}$.

Figure 6 shows the dendrogram made for the plots using the pair group method (UPGMA) based on the Sorensen index. Two distinct groups were formed between the plots, where the first group consists of plots 5 and 6 , and the second group comprises plots $1,2,3$, and 4, indicating similarity between them.

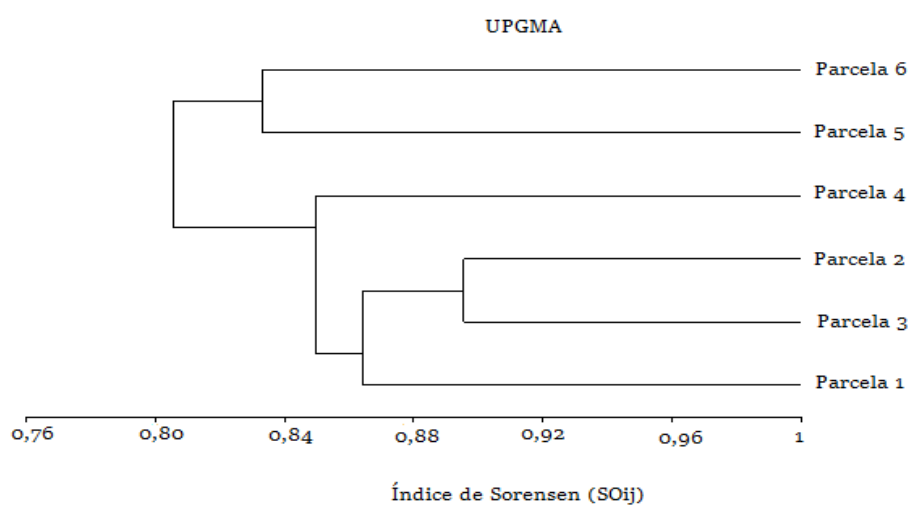

Figure 6. Dendrogram obtained from the Sorensen Similarity Index for the presence and absence of species in the 6 sampling plots of the study area.

Figura 6. Dendrograma obtido a partir do Índice de Similaridade de Sorensen, para os dados de presença e ausência das espécies, nas 6 parcelas amostrais da área de estudo.

Moreover, plots 5 and 6 were shown to be more similar than the others. These plots were the ones with the highest H' index values. Still observing the same figure, one can see that plot 4 was the most dissimilar from the others in the second group (plots 1,2,3, and 4).

\section{DISCUSSION}

Several botanical families found in the Amazon have high economic potential. Among them, species of families Fabaceae (882), Lecythidaceae (769), and Sapotaceae (609) stand out, since these families had the highest importance value indices (IVI) of this study. Studying a Dense Ombrophilous Forest area in Roraima State, Condé and Tonini (2013) found higher species richness concentration in the botanical families Fabaceae, Lecythidaceae, and Sapotaceae, with 1,883, 609, and 434 individuals, respectively, similar to the results found in this study.

FLORESTA, Curitiba, PR, v. 49, n. 4, p. 793 - 802, out/dez 2019.

Ramos, Y. A. et.al.

ISSN eletrônico 1982-4688

DOI: $10.5380 /$ rf.v49 i4.59264 
In the present study, Fabaceae was the family with the highest species richness (48 species), which was also observed in other studies conducted in the Legal Amazon by Gonçalves and Santos (2008), Carim et al. (2013), Almeida et al. (2012), and Oliveira et al. (2008).

The most abundant species were Eschweilera coriacea, Vouacapoua americana, Tetragastris altissima, Inga heterofila, Syzygiopsis oppositifolia, Eschweilera odora, Pouteria laurifolia, Chrysophyllum lucentifolium, and Sagotia brachysepala, which together accounted for $39.34 \%$ of the sampled individuals. The basal area was $1.18 \mathrm{~m}^{2} /$ ha for Vouacapoua americana; $1.34 \mathrm{~m}^{2} / \mathrm{ha}$ for Tetragastris altíssima; $0.58 \mathrm{~m}^{2} / \mathrm{ha}$ for Inga heterophylla; $1.49 \mathrm{~m}^{2} /$ ha for Syzygiopsis oppositifolia; and $1.3 \mathrm{~m}^{2} /$ ha for Eschweilera coriacea, accounting for $40.38 \%$ of the total sampled basal area (14.51 m²/ha). Despite their high density, Vouacapoua americana, Manilkara dardanoi, and Syzyogiopsis oppositifolia are considered endangered, vulnerable to extinction, and nearly threatened, respectively (MARTINS \& MARTINELLI, 2013), which can be explained since these species are of great commercial interest.

Thirty-one species (15.89\% of richness) were represented by only one individual. These species accounted for $0.86 \%$ of the total individuals. The overall average for the variable DBH was $44.86 \mathrm{~cm} \pm 21 \mathrm{~cm}$, with $\mathrm{CV}=47.8 \%$. For commercial height, the overall average was $11.98 \mathrm{~m} \pm 3 \mathrm{~m}$, with $\mathrm{CV}=28.51 \%$. These are considered very high values, and classify the areas as heterogeneous. These species were also cited by Flores $e t$ al. (2012) when studying an annual production unit (UPA) in this same area. The authors found these same species by analyzing the $100 \%$ inventory.

Among the most harvested commercial species for wood production in Pará State is Eschweilera coriacea. This species, classified as a climax species, has high commercial value and is found in the area at a density of 11.05 ind./ha. This value is much lower than that found by Alvino et al. (2005) in Bragantina-PA (77 ind./ha). The authors observed this value in a secondary forest area with 30 years of succession. Belonging to a family farmer, the area was abandoned after successive annual cultivation of maize, cassava, and rice.

For Vouacapoua americana, also considered a climax species, density was 6.61 ind./ha. Moreover, the horizontal structure showed that $18.40 \%$ of the individuals are in the range of $10-30 \mathrm{~cm} ; 44.60 \%$ between $30-50$ $\mathrm{cm}$; and $36.20 \%$ are larger than $50 \mathrm{~cm}$. The vertical structure showed that $45.18 \%$ are between $6-10 \mathrm{~m} ; 36.29 \%$ between $11-14 \mathrm{~m} ; 14.57 \%$ between $14-16 \mathrm{~m}$; and $3.96 \%$ are higher than $17 \mathrm{~m}$. The average DBH is $45.87 \mathrm{~cm} \pm$ $14.85 \mathrm{~cm}$. Total height averaged $11.23 \mathrm{~m} \pm 2.87 \mathrm{~m}$.

For species Tetragastris altissima, the horizontal structure showed that $5.89 \%$ of individuals had DBH between $10-30 \mathrm{~cm} ; 36.21 \%$ between $30-40 \mathrm{~cm}$; and $57.89 \%$ higher than $50 \mathrm{~cm}$. Average DBH was thus $52.40 \mathrm{~cm}$ $\pm 12.90 \mathrm{~cm}$. The average height was $10.07 \mathrm{~m} \pm 2.57 \mathrm{~m}$. This shade tolerant species, with a density of 6.06 ind./ha in the area, is of great relevance to forest ecology, performing well to establish new individuals and high survival rates (MEWS et al., 2012a). Its wood can be used in civil construction and charcoal production, and its bark exudate can be used in essence production and for medicinal purposes (RIBEIRO et al., 2015). In addition, the species has potential for studies aimed at identifying individuals for restoration of altered areas, demonstrating desirable characteristics to be indicated for forest management and recovery of degraded areas (MEWS et al., 2012).

For species Syzygiopsis oppositifolia, with a density of 3.78 ind./ha, its horizontal structure showed $11.36 \%$ of individuals between $10-30 \mathrm{~cm} ; 20.45 \%$ between $30-50 \mathrm{~cm}$; and $65.90 \%$ of individuals with DBH higher than $50 \mathrm{~cm}$, averaging $59.20 \mathrm{~cm} \pm 19.77 \mathrm{~cm}$. Its vertical structure, in turn, showed $19.31 \%$ of individuals between 6-10 m; 66\% between 11-14 m; and 26.13\% between 14-16 m, averaging $15 \mathrm{~m} \pm 3.54 \mathrm{~m}$.

The horizontal structure of Inga heterofila showed that $49.58 \%$ of individuals were between $10-30 \mathrm{~cm}$; $31.70 \%$ between $30-50 \mathrm{~cm}$; and $18.72 \%$ had a DBH higher than $50 \mathrm{~cm}$. Its vertical structure, in turn, showed $61.21 \%$ of individuals between $6-10 \mathrm{~m} ; 29.82 \%$ between $11-13 \mathrm{~m}$; and $8.97 \%$ between $14-16 \mathrm{~m}$ in height. Average DBH and height were $35.27 \mathrm{~cm}$ and $10.18 \mathrm{~m}$, respectively, with standard deviation of $17.55 \mathrm{~cm}$ and $2.35 \mathrm{~m}$.

Diversity indices showed that the studied area presents a relatively high diversity, since the Shannon index was above 3.60 in all plots. Pielou evenness, in turn, was between 0.81 and 0.86 , values already found in other studies for dense forest areas in the Amazon. Table 2 shows that the average diversity index between plots was 3.83, a better result than those of Silva et al. (2008), who found a value of 2.71 in Manaus-AM, and Condé and Tonini (2012), who found a value of 3.27 in Roraima State. Furthermore, Almeida et al. (2012) also studied a Dense Ombrophilous Forest area, managed in Santarem-PA, in the Legal Amazon, and obtained an H' index of 4.39, higher than that found in this study. This difference between tropical forests may occur because there is a greater dominance of some species within the community and a lower floristic homogeneity in terms of gender. For Pielou evenness (J'), the results of this study were similar to those found by Almeida et al. (2012) in SantarémPA.

Although the diameter distribution resembled an inverted J (Figure 5), this forest is not balanced, that is, the De Liocourt constant $(\mathrm{q})$ does not remain the same throughout the diameter classes, with a large number of 
smaller and thinner individuals in the first diameter classes, indicating that there was anthropic disturbance/forest management in this area.

\section{CONCLUSIONS}

With the results obtained in this study, we can conclude that:

- The studied area has a high floristic diversity in the tree stratum. However, this large number of individuals is concentrated in a few families: Fabaceae (882), Lecythidaceae (769), and Sapotaceae (609).

- The most structurally important species were Eschweilera coriacea (DC.) S.A.Mori, Vouacapoua americana Aubl., Tetragastris altissima (Aubl.), Syzygiopsis oppositifolia Ducke, and Inga heterophylla Willd., which together presented the highest IVI, totaling $39.34 \%$ of the individuals sampled.

- Among the species with the highest IVI, Vouacapoua americana and Manilkara dardanoi should be preserved. It is suggested that they be used for restoration of the areas most affected by management, as they are endangered and vulnerable to extinction, respectively.

- The stand diameter distribution followed the common pattern of unequal rainforests (inverted J-shaped curve), with a large concentration of individuals considered as stock individuals that are critical to the ecological functions of the forest.

- The dendrogram showed great similarity between the plots and great homogeneity in the area.

\section{ACKNOWLEDGEMENTS}

To the companies Martins Agropecuária S/A and LN GUERRA Industrial e Comércio de Madeiras LTDA, for allowing research in the area and the use of data. To CAPES, for granting the scholarship.

\section{REFERENCES}

ALMEIDA, L. S. D.; GAMA, J. R. V.; OlIVEIRA, F. D. A.; CARVALHO, J. O. P. D.; GONÇALVES, D. C. M.; ARAÚJO, G. C. Fitossociologia e uso múltiplo de espécies arbóreas em floresta manejada, Comunidade Santo Antônio, município de Santarém, Estado do Pará. Acta Amazonica, v. 42, n. 2, p. 185-194, 2012.

ALVARES, C. A.; STAPE, J.L; SENTELHAS, P.C.; DE MORAES, G.; LEONARDO, J.; SPAROVEK, G. Köppen's climate classification map for Brazil. Meteorologische Zeitschrift, v. 22, n. 6, p. 711-728, 2013.

ALVINO, F. de O.; SILVA, M. F. F. da; RAYOL, B. P. Potencial de uso das espécies arbóreas de uma floresta secundária, na Zona Bragantina, Pará, Brasil. Acta Amazonica, Manaus, v. 35, n. 4, p. 413-420, 2005.

BRASIL. Lei No 11284/2006 - Dispõe sobre a gestão de florestas públicas para a produção sustentável; altera as Leis nos 10.683, de 28 de maio de 2003, 5.868, de 12 de dezembro de 1972, 9.605, de 12 de fevereiro de 1998, 4.771, de 15 de setembro de 1965, 6.938, de 31 de agosto de 1981, e 6.015, de 31 de dezembro de 1973; e dá outras providências. Diário Oficial da União, Brasília, DF, dois de março de dois mil e seis. Disponível em: http://www2.mma.gov.br/port/conama/legiabre.cfm?codlegi=485. Acesso em 21/01/2019.

CARIM, Marcelo de Jesus Veiga et al. Composição e Estrutura de Floresta Ombrófila Densa do extremo Norte do Estado do Amapá, Brasil. Biota Amazônia (Biote Amazonie, Biota Amazonia, Amazonian Biota), v. 3, n. 2, p. $1-10,2013$.

CASTRO, Maria Soraia Aguiar et al. IMPACTOS DA EXPLORAÇÃO FLORESTAL NA ESTRUTURA E NA COMPOSIÇÃO FLORÍSTICA DA VEGETAÇÃO REMANESCENTE EM ÁREA MANEJADA NA FLORESTA NACIONAL DO TAPAJÓS, BELTERRA, PARÁ. Revista Agroecossistemas, v. 10, n. 2, p. 125$135,2018$.

CONDÉ, T. M.; TONINI, H. Fitossociologia de uma floresta ombrófila densa na Amazônia Setentrional, Roraima, Brasil. Acta Amazonica. v. 43, n. 3, p. 247-260, 2013.

Das FlORES, O. M. M.; de QUEIROZ, W. T.; PINHEIRO, J. G.; Oliveira, F. A.; Moraes, A.; Valente, M. D. R. Comparação de tamanhos e distâncias de subparcelas aplicadas em processo de amostragem por conglomerado Comparison of sizes and distances of subplots applied in the process of cluster sampling. Acta Amazonica, v. 42, n. 3, p. 345-354, 2012.

DA SILVA, K. E.; FERREIRA, M. M.; MATOS, F. D. A. Composição florística e fitossociologia de espécies arbóreas do Parque Fenológico da Embrapa Amazônia Ocidental. Acta Amazonica, v. 38, n. 2, p. 213-222, 2008.

FLORESTA, Curitiba, PR, v. 49, n. 4, p. 793 - 802, out/dez 2019.

Ramos, Y. A. et.al.

ISSN eletrônico 1982-4688

DOI: $10.5380 /$ rf.v49 i4.59264 
DE QUEIROZ, Waldenei Travassos et al. Análise estrutural da unidade conglomerada cruz de malta na Floresta Nacional do Tapajós, estado do Pará, Brasil. Floresta, v. 41, n. 1, 2011.

DOS SANTOS, Humberto Gonçalves et al. Sistema brasileiro de classificação de solos. Brasília, DF: Embrapa, 2018., 2013.

DOS SANTOS, M. J. F.; de ANDRADE, V. C. L.; FREITAS, B. C.; de SOUZA FERREIRA, R. Q.; BANDEIRA, S. B.; de SOUZA, P. B. Phytosociology and diametric structure of a fragment in the cerrado sensu stricto, south of tocantins. Scientia Agraria Paranaensis, v. 16, n. 3, p. 328-334, 2017.

ESPADA, A. L. V.; PIRES, T.I.P.; LENTINI, M.A.W.; BITTENCOURT, P.R.G. Manejo florestal e exploração de impacto reduzido em florestas naturais de produção da Amazônia. Informativo Técnico I IFT. Belém, IFT, 2015,32 p.

GONÇALVES, F. G.; SANTOS, J. dos. Composição florística e estrutura de uma unidade de manejo florestal sustentável na Floresta Nacional do Tapajós, Pará. Acta Amazonica, v. 38, n. 2, p. 229-244, 2008.

INSTITUTO BRASILEIRO DE GEOGRAFIA E ESTATISTICA - IBGE. Manual técnico da vegetação brasileira. Rio de Janeiro: 2012. 271p.

MARTINS, Eline Matos; MARTINELLI, Gustavo. Listas Vermelhas e Estratégias de Conservação: a atuação do Centro Nacional de Conservação da Flora (CNCFlora) com as espécies da Flora ameaçadas de extinção. II Simpósio sobre a biodiversidade da mata atlântica. Rio de Janeiro, p. 23-28, 2013.

MEWS, Henrique Augusto et al. Análise temporal das distribuições de diâmetros e alturas de uma Floresta Estacional Semidecídua na transição Cerrado-Floresta Amazônica, leste de Mato Grosso, Brasil. Biotemas, v. 25 , n. 2, p. 33-43, 2012.

OLIVEIRA, A. D.; AMARAL, I.D.; RAMOS, M. B. P.; NOBRE, A. D.; COUTO, L. B.; SAHDO, R. M. Composição e diversidade florístico-estrutural de um hectare de floresta densa de terra firme na Amazônia Central, Amazonas, Brasil. Acta Amazonica, v. 38, n. 4, p. 627-642, 2008.

RIBEIRO, R.B.S.; GAMA, J.R.V.; MARTINS, S.V.; MORAES, A.; DOS SANTOS, C.A.A.; DE CARVALHO, A.N. Estrutura florestal em projeto de assentamento, comunidade São Mateus, município de Placas, Pará, Brasil. Ceres, v. 60, n. 5, 2015.

SANTOS, Robson dos et al. Vegetação arbustivo-arbórea em uma restinga de Jaguaruna, litoral sul do Estado de Santa Catarina, Brasil. Revista Ambiente e Água, v. 12, n. 1, 2017.

SALOMÃO, R.P.; SANTANA, A.C.; BRIENZA JÚNIOR, S.; GOMES, V.H.F. Análise fitossociológica de floresta ombrófila densa e determinação de espécies-chave para recuperação de área degradada através da adequação do índice de valor de importância. Boletim do Museu Paraense Emílio Goeldi. Ciências Naturais, v.7, p.57-102, 2012.

SILVA, W. A. S.; CARIM, M. D. J. V.; DA SILVA GUIMARÃES, J. R.; TOSTES, L. D. C. L. Composição e diversidade florística em um trecho de floresta de terra firma no sudoeste do Estado do Amapá, Amazônia oriental, Brasil. Biota Amazônia. v. 4, n. 3, p. 31-36, 2014.

SOARES, C. P. B., NETO, FRANCISCO de P. e SOUZA, A. L. de. Dendrometria e Inventário Florestal. Viçosa: Ed. UFV, 2006. 276p. 